\title{
ANNOUNCEMENT
}

\section{New silicate rock reference materials issued from the Geological Survey of Japan, 1984}

The Geological Survey of Japan is processing a series of geochemical rock samples to be issued as reference materials for major, minor and trace elements, isotopic compositions, geological ages and physical constants.

Granodiorite JG-1 was prepared in 1967 and basalt JB-1 in 1968. The supply of these two rocks, however, became exhausted in 1981, after settlement of 75 analytical components. Nine new whole-rock sample powders, JA-1, JB-1 a, JB-2, JB-3, JG-1 a, JGb-1, JP-1, JR-1 and JR-2 have been added to the Geological Survey of Japan's Rock SRMs Program in 1982 and 1983.

Any geologist, geochemist or analyst interested in participating in our program is invited to write to Liaison Officer of Reference Materials, Chemistry Section, Geochemistry and Technical Service Department, Geological Survey of Japan, 1-1-3 Higashi, Yatabe, Ibaraki, 305 Japan. We would appreciate reports on the analysis of these rocks as well as of JG-1 and JB1 .

JA-1 Andesite Hakone Volcano (Somma lava)

Collected from Manazuru, Ashigarashimo-gun, Kanagawa Prefecture.

JB-1a Basalt Sasebo (Alkali basalt) Collected from the MyokanjiToge, Sasebo, Nagasaki Prefecture. Replacement sample of JB-1, 1968.

JB-2 Basalt $\overline{\mathrm{O}}$-Shima Volcano (Tholeiitic basalt)

Collected from the northern rim of the central pit of the Mihara crater, O-Shima, To- kyo.

JB-3 Basalt Fuji Volcano (High alumina basalt)

Collected from Narusawa, Minamitsuru-gun, Yamanashi Prefecture. Aokigahara lava flow.

JG-1a Granodiorite Sori

Collected from Sori, Azumamura, Seta-gun, Gumma Prefecture. Replacement sample of JG-1, 1967.

JGb-1 Gabbro Utsushi-ga-Take

Collected from mount Utsushi-ga-Take, Funehiki, Tamura-gun, Fukushima Prefecture.

JP-1 Peridotite Horoman

Collected from Horoman, Samani-gun, Kokkaido.

JR-1 Ryolite Wada Toge (Obsidian)

Collected from the northern part of Wada-Toge, Wadamura, Chiisagata-gun, Nagano Prefecture.

JR-2 Rhyolite Wada Toge (Obsidian) Collected from the southern part of Wada-Toge, Shimosuwa, Suwa-gun, Nagano Prefecture.

JA-1, JB-2 and JR-1 were prepared in April, 1982.

JB3- JGb-1 and JR-1 were prepared in November, 1982.

JP-1, JG-1a and JB-1 a were prepared in December, 1983.

About $100 \mathrm{~g} /$ bottle. Some additional samples of other rocks are under processing. 
Reports on JG-1 and JB-1 (ANDO, 1967; Kurasawa, 1968; ANDo et al., 1971; ANDo et al., 1974; ANDo et al., 1975; ANDo et al., 1983), and on six new rocks: JA-1, JB-2, JB-3, JGb-1, JR-1 and JR-2 (ANDo et al., 1983; TERASHIMA

\section{REFERENCES}

ANDo, A. (1967) A new silicate rock standard, JG-1 issued from the Geological Survey of Japan. Geochem. J. 1, 155.

ANDO, A., KURASAWA, H., OHMORI, T. and TAKEDA, E. (1971) 1971 compilation of data on rock standards JG-1 and JB-1 issued from the Geological Survey of Japan. Geochem. J. 5, 151-164.

Ando, A., Kurasawa, H., OHMORI, T. and TAKEDA, E. (1974) 1974 complilation of data on the GSJ geochemical reference samples JG-1 granodiorite and JB-1 basalt. Geochem. J. 8, 175-192.

Ando, A., Kurasawa, H. and UChiumi, S. (1975)

Evaluation of $\mathrm{Rb}, \mathrm{Sr}, \mathrm{K}$ and $\mathrm{Na}$ contents of the et al., 1984) have been published.

Atsushi ANDo

Geological Survey of Japan

Yatabe, Ibaraki, Japan

GSJ JG-1 granodiorite and JB-1 basalt. Chishitsu Chosasho Geppo 26, 335-348.

Ando, A., OHMORI, T. and Terashima, S. (1983) New GSJ silicate rock reference samples and their chemical compositions. Abstr. Annual Meering, Geochemical Society of Japan, 168-169 (in Japanese).

KuRASAWA, H. (1968) A new silicate rock standard, JB-1 issued from the Geological Survey of Japan. Geochem. J. 2, 185.

Terashima, S., Yamashige, T. and ANDo, A. (1984) Determination of major and minor elements on the six GSJ rock reference samples. Chishitsu Chosasho Geppo 35, 171-177. 